\title{
Antifungal activity of Leaf and Pericarp of polyalthia longifolia Against Pathogens Causing Rhizome Rot of Ginger
}

\author{
Dileep $\mathbf{N}^{1}$, Syed Junaid ${ }^{1}$, Rakesh $\mathrm{KN}^{1}$, Prashith Kekuda $\mathrm{TR}^{1^{*}}$ and Noor Nawaz $\mathrm{AS}^{2}$ \\ ${ }^{1}$ Department of Microbiology, SRNMN College of Applied Sciences, NES Campus, Balraj Urs Road, \\ Shivamogga-577201, Karnataka, India \\ ${ }^{2}$ Organic Farming Research Centre, ZARS, Navile, Shivamogga-577204, Karnataka, India
}

\begin{abstract}
The aqueous extracts of leaf, unripe pericarp and ripe pericarp of Polyalthia longifolia were assessed in vitro for inhibitory activity against Fusarium oxysporum f.sp. zingiberi and Pythium aphanidermatum isolated from rhizome rot specimen of ginger. The antifungal activity was determined by poison food technique. The extracts have shown dose dependent inhibition of mycelial growth of test fungi. The extracts were more effective in inhibiting $F$. oxysporum than $P$. aphanidermatum. Ripe pericarp extract inhibited test fungi to maximum extent followed by unripe pericarp extract and leaf extract respectively. The extracts of $P$. longifolia were found effective against ginger rhizome rot pathogens. Further, field experiments are to be carried out to recommend the extracts against the disease.
\end{abstract}

\section{INTRODUCTION}

Plants have been serving mankind as an important source of food, timber, fodder, medicine etc., Plants are very vulnerable for attack by a variety of pathogens such as bacteria, fungi, mycoplasma, actinomycetes \& nematodes which causes a range of diseases in plants. Phytopathogens, in particular fungi are responsible for causing poor establishment and stand loss in a variety of economically important crops (Cowan, 1999; Farooq et al., 2010). Control of the disease by the use of chemicals is not so beneficial due to high cost, breakdown of resistance, residual problem and deleterious effect on non-target organisms including humans. This has necessitated search for alternatives for controlling the rhizome rot of ginger (Pandey et al., 2010). Antifungal agents based on natural products have always been promising in the control of fungi. The secondary metabolites produced by these plants have shown to affect the fungal agents. Moreover, these agents are not toxic and are decomposed easily. Numerous literatures have highlighted the inhibitory effect of plants and their possible utilization for control of plant diseases (Singh et al., 2006; Shrestha and Tiwari, 2009; Farooq et al., 2010; Nunez et al., 2010; Gupta and Tripathi, 2011).

Zingiber officinale Rosc. (ginger) belonging to the family Zingiberaceae is an important commercial crop grown for its aromatic rhizomes which are used as a spice and a medicine (Sharma et al., 2010). It is an important crop that earns a sizeable amount of foreign exchange for the country (Tarafdar and Saha, 2007). India is the largest producer of ginger accounting for about $1 / 3^{\text {rd }}$ of total world output. Ginger is grown in various states such as Kerala, Karnataka, West Bengal, Andhra Pradesh, Orissa, Arunachal Pradesh and Sikkim (Sharma et al., 2010; Kumar et al., 2008). The production of ginger, however, is largely affected by diseases caused by bacteria, fungi, viruses, mycoplasma and nematodes. The crop suffers from diseases like bacterial wilt caused by Ralstoniasolanacearum, rhizome rot caused by Pythium species, Fusarium species, Sclerotium species, Pseudomonas species and others (Paretet al., 
Dileep et al.,

2010; Kavyashree, 2011; Sharma et al., 2010; Senapati \& Ghose, 2005; Dake \& Edison, 1989). The disease management involves cultural, biological and chemical approaches for pathogen suppression (Bhai et al., 2005).

Polyalthia longifolia Thw. (Annonaceae) is native of Sri Lanka and is grown in gardens throughout the warmer parts of India. Stem bark contains clerodane diterpenes, polyalthialdoic acid and kolavenic acid. The stem and its bark also contain the cytotoxic aporphine alkaloid, liriodenine, besides nor-oliveroline and oliveroline-beta-N-oxide. Azafluorene alkaloids are also present in the bark and leaves (Khare, 2007). The plant is shown possessing antimicrobial (Faizi et al., 2008), antioxidant (Manjula et al., 2010), antitumor (Manjula et al., 2010), antiulcer (Malairajan et al., 2008), antileishmanial (Pal et al., 2011), hypotensive (Saleem et al., 2005), anti-hyperglycemic (Ghosh et al., 2010), anti-inflammatory (Tanna et al., 2009), hepato-protective (Tanna et al., 2009), anticataract-ogenesis activity (Sivashanmugam and Chatterjee, 2012) \& others. Juice extracted from the fresh stem bark is taken orally to treat indigestion in Uthiramerur taluk, Kancheepuram district, Tamil Nadu, India (Sugumaran et al., 2010). The present study was designed to investigate inhibitory effect of aqueous extract of leaf and pericarp (ripe and unripe) of $P$. longifolia against Fusarium oxysporum f.sp. zingiberi \& Pythium aphanidermatum isolated from rhizome rot specimen of ginger.

\section{MATERIALS AND METHODS}

\section{Isolation of Fungi from Diseased Specimen of Ginger}

Ginger specimens showing water soaked lesions along with yellowing and lodging of the pseudostem were selected for isolation of test fungi viz., $P$. aphanidermatum and $F$. oxysporum f.sp. zingiberi. Ginger specimens were collected from an infected field at Hosanagara (Taluk) of Shivamogga (District), Karnataka. The fungi were isolated on potato dextrose agar (PDA) and maintained on PDA.

\section{Collection and Identification of Plant Materials}

The leaves and fruits (ripe and unripe) of $P$. longifolia were collected from outskirts of Shivamogga during May 2012. The plant specimens were authenticated by Dr. Vinayaka K.S, lecturer, Department of Botany, Indira Gandhi Government College, Sagara, Karnataka.
Sci. technol. arts Res. J., Jan-Mar 2013, 2(1): 56-59

\section{Extraction}

The leaves and pericarp of ripe and unripe fruits were cut into small pieces, shade dried and powdered using blender. For extraction, $10 \mathrm{~g}$ of powdered material was added to $100 \mathrm{ml}$ of distilled water and boiled for about half an hour. The content was filtered through 4-fold muslin cloth followed by Whatmann filter paper and used for antifungal studies (Kekuda et al., 2010).

\section{Antifungal Activity of Leaf \& Pericarp Extracts}

The antifungal efficacy of leaf and pericarp extracts was determined by Poisoned food technique. PDA media amended with different concentrations of leaf and pericarp extracts (10 and $20 \%$ ) were sterilized by autoclaving and added to labelled petriplates. Fungal discs of $5 \mathrm{~mm}$ diameter were cut from the periphery of 5 days old culture of $F$. oxysporum and $P$. aphanidermatum and were transferred aseptically on PDA plates poisoned with extracts and incubated for 5 days at $28^{\circ} \mathrm{C}$. Colony diameters in mutual perpendicular directions were measured on the fifth day. The experiment was repeated twice and average colony diameter was recorded. Antifungal activity was recorded in terms of inhibition of mycelial growth (\%) and calculated using the formula:

\section{Inhibition of mycelial growth $(\%)=(C-T / C) \times 100$}

where ' $C$ ' is average diameter of fungal colony in control plates and ' $T$ ' is average diameter of fungal colony in poisoned plates (Gupta and Tripathi, 2011).

\section{RESULTS AND DISCUSSION}

The poisoned food technique was employed to determine inhibitory efficacy of different concentrations of leaf, ripe pericarp and unripe pericarp extracts of $P$. longifolia against $F$. oxysporum f.sp. zingiberi and $P$. aphanidermatum and the result is presented in Table 1 and 2 . The average diameter of colonies of test fungi in poisoned plates was markedly lesser than that of colony diameter in control plates which is indicative of antifungal potential of extracts. The inhibition was concentration dependent. Among fungi tested, susceptibility to extracts was higher in F. oxysporum f.sp. zingiberi than P. Aphani dermatum. Ripe pericarp extract caused highest inhibition of test fungi followed by unripe pericarp extract and leaf extract respectively.

Crop loss due to root rot-causing fungal pathogens is a significant problem. The most common method of control is the use of chemical fungicides. However, environmental concerns, costs, development of resistance in pathogens increased interest in alternatives such as plant 
Dileep et al.,

Table 1: Effect of leaf and pericarp extracts on mycelial growth of test fungi.

\begin{tabular}{|c|c|c|c|}
\hline \multirow[b]{2}{*}{ Treatment } & \multirow{2}{*}{$\begin{array}{c}\text { Conce- } \\
\text { ntration } \\
(\%)\end{array}$} & \multicolumn{2}{|c|}{ Colony diameter in $\mathrm{cm}$} \\
\hline & & $\begin{array}{c}F . \\
\text { oxysporum }\end{array}$ & $\begin{array}{l}\text { P. Aphani- } \\
\text { dermatum }\end{array}$ \\
\hline Control & - & 3.5 & 3.5 \\
\hline \multirow{2}{*}{ Leaf } & 10 & 2.5 & 2.9 \\
\hline & 20 & 1.9 & 2.3 \\
\hline \multirow{2}{*}{$\begin{array}{c}\text { Ripe } \\
\text { pericarp }\end{array}$} & 10 & 1.4 & 1.8 \\
\hline & 20 & 0.8 & 1.2 \\
\hline \multirow{2}{*}{$\begin{array}{l}\text { Unripe } \\
\text { pericarp }\end{array}$} & 10 & 1.6 & 2.1 \\
\hline & 20 & 1.0 & 1.6 \\
\hline
\end{tabular}

Table 2: Inhibition of test fungi (\%) by leaf and pericarp extracts.

\begin{tabular}{cccc}
\hline \multirow{2}{*}{ Treatment } & \multirow{2}{*}{$\begin{array}{c}\text { Conce } \\
\text { ntration } \\
\text { (\%) }\end{array}$} & \multicolumn{2}{c}{ Percent inhibition } \\
\cline { 3 - 4 } & oxysporum & $\begin{array}{c}\boldsymbol{P} \text {. } \\
\text { aphanidermatum }\end{array}$ \\
\hline \multirow{2}{*}{ Leaf } & 10 & 28.57 & 17.14 \\
& 20 & 45.71 & 34.28 \\
Ripe & 10 & 60.00 & 48.57 \\
pericarp & 20 & 77.14 & 65.71 \\
Unripe & 10 & 54.28 & 40.00 \\
pericarp & 20 & 71.42 & 54.28 \\
\hline
\end{tabular}

extracts, antagonistic microbes and others to traditional synthetic chemical fungicides (Sealy et al., 2007). Plants and plant products have shown to be useful candidates for prevention and control of phytopathogenic fungi. Several studies have shown that the crude extracts and purified components of plants possess inhibitory activity against fungal agents including plant pathogenic fungi. The volatile oil and acetone extract of Foeniculum vulgare were shown to exhibit concentration dependent antifungal activity against species of Aspergillus, Penicillium, Fusarium and Curvularia (Singh et al., 2006). Shrestha and Tiwari (2009) observed dose dependent inhibitory effect of crude extracts of some medicinal plants against Fusarium solani (Mart.) Sacc., causing dry potato tuber rot. Farooq et al. (2010) showed the efficacy of plant extracts against Sclerotium rolfsii, causative agent of root rot of sugar beet and observed maximum inhibition of the fungus by Azadirachta indica followed by Cassia fistula, Cannabis sativa and others. Nunez et al. (2010) observed the inhibitory effect of hexane and ethanol extracts of aerial parts of Juniperus lucayana against phytopathogenic fungus Botrytis cinerea by poisoned food technique. Gupta and Tripathi
Sci. technol. arts Res. J., Jan-Mar 2013, 2(1): 56-59

(2011) showed fungitoxic activity of Solanum torvum against Fusarium sacchari.

Poisoned food technique has been routinely employed to screen the effect of plants and their compounds against fungi. The antifungal activity is observed as reduction in the mycelial growth of fungus in poisoned plates when compared to control plates. It has been employed by several researchers to evaluate antifungal activity of plants (Nunez et al., 2010; Gupta and Tripathi, 2011). In the present study, we have investigated the effect of aqueous extracts of leaf and pericarp of $P$. longifolia against mycelial growth of two pathogenic fungi $F$. oxysporum f.sp. zingiberi and $P$. aphanidermatum isolated from soft rot specimen of ginger. The extracts have shown marked concentration dependent inhibition of mycelial growth of test fungi indicating the presence of antifungal principles in the aqueous extracts. In an earlier study, Sagar et al. (2007) showed the fungitoxic efficacy of some plant extracts against $P$. aphanidermatum and $F$. solani isolated from rhizome rot specimen of ginger. It was found that Azadirachta indica and Ferula asafeotida showed maximum inhibition of mycelial growth of $P$. aphanidermatum and $F$. solani respectively.

\section{CONCLUSION}

From the results of the present study, it is concluded that the leaf and pericarp extracts of $P$. longifolia are effective against ginger rhizome rot pathogens. Further, field experiments are to be carried out in order to recommend the bioactive extracts against the disease.

\section{ACKNOWLEDGEMENTS}

The authors are sincerely thankful to HOD, Department of Microbiology \& Principal, SRNMN College of Applied Sciences, Shivamogga and NES, Shivamogga for providing facilities to conduct work and giving moral support.

\section{REFERENCES}

Bhai, R.S., Kishore, V.K., Kumar, A., Anandaraj, M., Espen, S.J. (2005). Screening of rhizobacterial isolates against soft rot disease of ginger (Zingiber officinale Rosc.). Journal of Spices and Aromatic Crops ,14(2), 130-136.

Cowan, M.M. (1999). Plant extracts as antimicrobial agents. Clinical Microbiology Reviews, 12(4), 564582

Dake, G.N., Edison, S. (1989). Association of pathogens with rhizome rot of ginger in Kerala. Indian Phytopathology , 42(1), 116-119 
Dileep et al.,

Faizi, S., Khan, R.A., Mughal, N.R., Malik, M.S., Sajjadi, K.E., Ahmad, A. (2008). Antimicrobial activity of various parts of Polyalthia longifolia var. pendula: Isolation of active principles from the leaves and the berries. Phytotherapy Research. 22(7), 907-912.

Farooq, M.A., Iqbal, U., Iqbal, S.M., Afzal, R., Rasool A. (2010). In-vitro evaluation of different plant extracts on mycelial growth of Sclerotium rolfsii the cause of root rot of sugar beet. Mycopath, 8(2), 8184.

Ghosh, G., Kar, D.M., Subudhi, B.B., Mishra, S.K. (2010). Antihyperglycemic and antioxidant activity of stem bark of Polyalthia longifolia var. angustifolia. Der Pharmacia Lettre, 2(2). 206-216.

Gupta, S.K., Tripathi, S.C. (2011). Fungitoxic activity of Solanum torvum against Fusarium sacchari. Plant Protection Science, 47(3), 83-91.

Kavyashree, R. (2009). An efficient in vitro protocol for clonal multiplication of Ginger- var. Varada. Indian Journal of Biotechnology, 8, 328-331.

Kekuda, T.R.P., Kavya, R., Shrungashree, R.M., Suchithra, S.V. (2010). Screening of selected single and polyherbal ayurvedic medicines for antibacterial \& antifungal activity. Ancient Science of Life, 29(3), 22-25.

Khare, C.P. (2007). Indian Medicinal Plants: An Illustrated Dictionary. Springer Verlag, Berlin, 341.

Kumar, A., Reeja, S.T., Bhai, R.S., Shiva, K. N. (2008). Distribution of Pythium myriotylum Drechsler causing soft rot of ginger. Journal of Spices and Aromatic Crops, 17(1), 5-10.

Malairajan, P., Gopalakrishnan, G., Narasimhan, S., Veni, K.J.K. (2008). Evaluation of antiulcer activity of Polyalthia longifolia (Sonn.) Thwaites in experimental animals. Indian Journal of Pharmacology, 40(3), 126-128.

Manjula, S.N., Kenganora, M., Parihar, V.K., Kumar, S., Nayak, P.G., Kumar, N., Pai, R.K.S., Rao, C.M. (2010). Antitumor and antioxidant activity of Polyalthia longifolia stem bark ethanol extract. Pharmaceutica Biology, 48(6), 690-696.

Nunez, Y.O., Salabarria, S., Collado, I.G., HernandezGalan, R. (2010). Antifungal activity of extracts and terpene constituents of aerial parts of Juniperus lucayana. The Revista Latinoamericana de Química, 38(3), 145-152.

Pal, D., Bhattacharya, S., Baidya, P., De, B.K., Pandey, J.N., Biswas, M. (2011). Antileishmanial activity of Polyalthia longifolia leaf extract on the in vitro growth of Leishmania donovani promastigotes. Global Journal of Pharmacology, 5(2), 97-100.

Pandey, A.K., Awasthi, L.P., Srivastva, J.P., Sharma, N. K. (2010). Management of rhizome rot disease of ginger (Zingiber officinale Rose L.). Journal of Phytology, 2(9), 18-20.
Sci. technol. arts Res. J., Jan-Mar 2013, 2(1): 56-59

Paret, M.L., Cabos, R., Kratky, B.A., Alvarez, A.M. (2010). Effect of plant essential oils on Ralstonia solanacearum Race 4 and bacterial wilt of edible ginger. Plant Disease, 94(5), 521-527.

Sagar, S.D., Kulkarni, S., Hegde, Y.R. (2007). Management of rhizome rot of ginger by botanicals. International Journal of Plant Science, 2(2), 155158.

Saleem, R., Ahmed, M., Ahmed, S.I., Azeem, M., Khan, R.A., Rasool, N., Saleem, H., Noor, F., Faizi, S. (2005). Hypotensive activity and toxicology of constituents from root bark of Polyalthia longifolia var. pendula. Phytotherapy Research, 19(10), 881884.

Sealy, R., Evans, M.R., Rothrock, C. (2007). The effect of a garlic extract and root substrate on soilborne fungal pathogens. HorTechnology, 17(2), 169-173.

Senapati, A.K., Ghose, S. (2005). Screening of ginger varieties against rhizome rot disease complex in eastern ghat high land zone of Orissa. Indian Phytopathology, 58(4), 437-439.

Sharma, B.R., Dutta, S., Roy, S., Debnath A., Roy, M.D. (2010). The effect of soil physico-chemical properties on rhizome rot and wilt disease complex incidence of ginger under hill agro-climatic region of West Bengal. Plant Pathology Journal, 26(2), 198202.

Shrestha, A.K., Tiwari, R.D. (2009). Antifungal activity of crude extracts of some medicinal plants against Fusarium solani (Mart.) Sacc. Ecoprint , 16, 75-78.

Singh, G., Maurya, S., de Lampasona, M.P., Catalan, C. (2006). Chemical constituents, antifungal and antioxidative potential of Foeniculum vulgare volatile oil and its acetone extract. Food Chemistry, $17,745-752$.

Sivashanmugam, A.T., Chatterjee, T.K. (2012). Anticataractogenesis activity of Polyalthia longifolia leaves extracts against glucose induced cataractogenesis using goat lenses in vitro. European Journal of Experimental Biology, 2(1), 105-113.

Sugumaran, M., Bharathi, V., Lakshmi, H.R.M. (2010). Ethnomedicinal Plants for Indigestion in Uthiramerur Taluk, Kancheepuram District, Tamil Nadu, India. Journal of Chemical \& Pharmaceutical Research, 2(6), 463-470.

Tanna, A., Nair, R., Chanda, S. (2009). Assessment of anti-inflammatory and hepatoprotective potency of Polyalthia longifolia var. pendula leaf in Wister albino rats. Journal of Natural Medicines, 63(1), 8085 .

Tarafdar, J., Saha, N. (2007). Correlation study on population dynamics of ginger soft rot inciting pathogens under different organic amendments, disease incidence and its survival in Darjeeling hill soils. Proceedings of the $13^{\text {th }}$ ISTRC Symposium, 165-169. 